\begin{tabular}{|c|c|c|c|}
\hline & $\begin{array}{l}\text { Time } \\
\text { constraints } \\
\text { (n) }\end{array}$ & $\begin{array}{l}\text { Being tired of } \\
\text { the treatment } \\
\text { (n) }\end{array}$ & $\begin{array}{l}\text { Problems with } \\
\text { vascular access } \\
\text { (n) }\end{array}$ \\
\hline Month 0 & 3 & 7 & 6 \\
\hline Month 6 & 3 & 4 & 2 \\
\hline Month 12 & 3 & 4 & 0 \\
\hline
\end{tabular}

non-compliant were monitored for 1 year, and it was determined that the rate of compliance increased only to $56.25 \%$ in our prospective cohort study.

Adolescent patients are more resistant to comply with recommended treatment plans. In this age group, the patients go through several biological, social, and emotional changes that influence their approach to the disorder [4]. Due to these factors, the non-compliance problem has a complicated nature that cannot be resolved through advising only. Treatment nonadherence is a chronic process in life-long chronic diseases such as hemophilia. As each patient is affected by different factors, it might be useful to conduct individual meetings with each patient instead of group trainings.

Keywords: Hemophilia, Compliance, Adolescent

Anahtar Sözcükler: Hemofili, Tedavi uyumu, Adölesan

Conflict of Interest: The authors of this paper have no conflicts of interest, including specific financial interests, relationships, and/or affiliations relevant to the subject matter or materials included.

\section{References}

1. van Os SB, Troop NA, Sullivan KR, Hart DP. Adherence to prophylaxis in adolescents and young adults with severe haemophilia: a quantitative study with patients. PLoS One 2017;12:e0169880.

2. Khair K. Compliance, concordance and adherence: what are we talking about? Haemophilia 2014;20:601-603.

3. Thornburg CD. Physicians' perceptions of adherence to prophylactic clotting factor infusions. Haemophilia 2008;14:25-29.

4. Brand B, Dunn S, Kulkarni R. Challenges in the management of haemophilia on transition from adolescence to adulthood. Eur J Haematol 2015;95(Suppl 81):30-35.

\title{
Bleomycin-Induced Flagellate Dermatitis
}

\section{Bleomisin ile Illişkili Flagella Dermatit}

(1) Esra Turan Erkek ${ }^{1}$, (1) Ceren Nur Karaali2 , (1) Güven Yılmaz ${ }^{1}$, (1) Emine Gültürk1

${ }^{1}$ Lütfi Kırdar Training and Research Hospital, Clinic of Hematology, Istanbul, Turkey

${ }^{2}$ Bahçeşehir University Faculty of Medicine, Istanbul, Turkey

To the Editor,

Bleomycin is a cytostatic, antineoplastic antibiotic that is used in both of the first-line treatments of Hodgkin lymphoma: ABVD (doxorubicin, bleomycin, vinblastine, dacarbazine) and BEACOPP (doxorubicin, bleomycin, vincristine, cyclophosphamide, etoposide, prednisone, procarbazine). The bleomycin hydrolase enzyme metabolizes bleomycin. This enzyme is not found in the skin or lung tissues; therefore, bleomycin accumulates in those areas and causes side effects [1]. The dermatologic side effects of bleomycin may vary from onycholysis, pruritus, and scleroderma-like skin changes to Stevens-Johnson syndrome. Flagellate dermatitis, resulting after bleomycin therapy, was originally described by Moulin et al. [2] in 1970 as "bleomycin-induced linear hyperpigmentation" [3]. Although the term "flagellate dermatitis" was described for bleomycin-induced dermatitis, other causes of this symptom have been defined over time (Table 1) [4]. The characteristic symptoms are pruritic linear hyperpigmentations, arranged in a flagellate pattern and developing, in particular, on the trunk. Even though the exact mechanism is not clear, minor skin traumas are thought to be responsible since they increase blood flow to the affected area and cause drug accumulation [1].

We present a 24-year-old female patient who was diagnosed in August 2016 with stage IIA Hodgkin lymphoma (right cervical, submandibular, and bilateral palatine tonsil involvement 
was observed in positron emission tomography/computed tomography). A BEACOPP chemotherapy regimen was chosen for first-line therapy. After the second cycle of BEACOPP, the patient developed generalized and intense pruritus along with the appearance of papules and plaques on her back, shoulders, and trunk, with a remarkable whip-like mark formation (Figures 1 and 2), which evolved into hyperpigmentation. There was no evidence of mucosal or systemic involvement. Contrary to expectations, there was no evidence of dermatographia. Flagellate dermatitis was diagnosed by the clinical features. The patient did not have a history of dermatomyositis, Still's disease, hypereosinophilic syndrome, or shiitake mushroom intake. The BEACOPP regimen was interrupted after three cycles of chemotherapy were completed. The skin lesions started to resolve two weeks after the bleomycin-inducing therapy was suspended.

Bleomycin-induced flagellate dermatitis is a dose-dependent reaction that usually occurs with total doses above $100 \mathrm{U}$ $[5,6]$. In contrast with these results, some patients develop skin symptoms after low doses. The incidence of developing flagellate dermatitis and consequent hyperpigmentation after receiving bleomycin treatment is reported between $8 \%$ and 22\% [7]. The lesions usually diminish 3-4 months after the interruption of the bleomycin treatment. Other than the suspension of the bleomycin treatment, no effective treatment has been reported for bleomycin-induced flagellate dermatitis. In the literature, there are some cases that report the use of topical or systemic corticosteroid treatments, as well as oral antihistamine treatments. However, it is stated that those treatments provide only symptomatic relief. The cessation of bleomycin is necessary to prevent further relapse [8]. We found it worthwhile to present our case since the development of this condition is rarely seen after a low dosage, the lesions disappear shortly after the suspension of the medication, and flagellate dermatitis is not observed with the other medications that our patient was receiving. Clinicians must be aware of this uncommon complication and act immediately to interrupt the causative agent.

\begin{tabular}{|l|l|}
\hline Table 1. Causes of flagellate dermatitis. \\
\hline True flagellation/mechanical & Religious punishment, torture, abuse, sadomasochism, dermatitis artefacta \\
\hline Chemotherapy-induced & Bleomycin, peplomycin, docetaxel, bendamustine \\
\hline Rheumatologic disorders & Dermatomyositis, adult-onset Still's disease \\
\hline Toxin-induced & Shiitake mushroom ingestion, cnidarian stings, Paederus and other insects \\
\hline Other pruritic dermatitis & Dermatographism, excoriations from pruritic conditions, phytophotodermatitis, poison ivy dermatitis \\
\hline Hypereosinophilic syndrome & - \\
\hline Chikungunya fever-induced & - \\
\hline Idiopathic & - \\
\hline
\end{tabular}

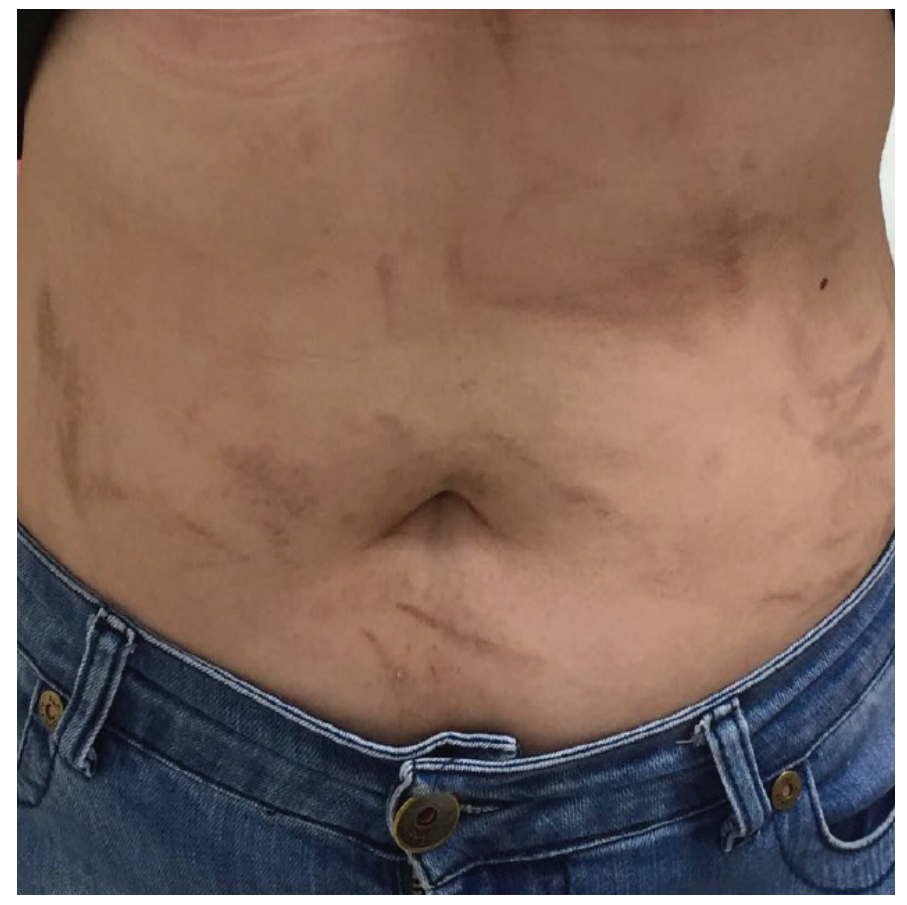

Figure 1. Flagellate dermatitis on trunk.

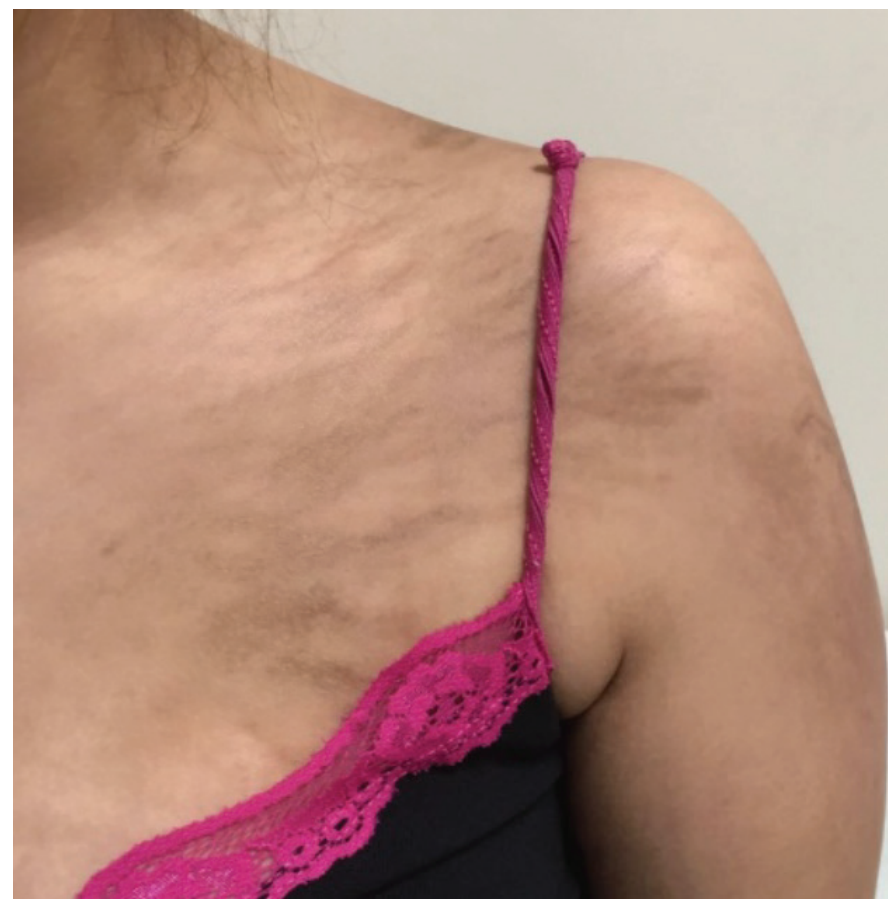

Figure 2. Flagellate dermatitis on extremity. 
Keywords: Bleomycin, Hodgkin lymphoma, Flagellate dermatitis

Anahtar Sözcükler: Bleomisin, Hodgkin Lenfoma, Flagella dermatit

Informed Consent: Received.

Conflict of Interest: The authors of this paper have no conflicts of interest, including specific financial interests, relationships, and/or affiliations relevant to the subject matter or materials included.

\section{References}

1. Diao DY, Goodall J. Bleomycin-induced flagellate dermatitis. CMAJ 2012;184:1280.
2. Moulin MMJ, Fière $B$, Beyvin A. Cutaneous pigmentation caused by bleomycin. Bull Soc Fr Dermatol Syphiligr 1970;293-296.

3. Bronner AK, Hood AF. Cutaneous complications of chemotherapeutic agents. J Am Acad Dermatol 1983;9:645-663.

4. Bhushan P, Manjul P, Baliyan V. Flagellate dermatoses. Indian J Dermatol Venereol Leprol 2014;80:149-152.

5. Vignini M, Miori L, Brusamolino E, Pelfini C. Linear streaking after bleomycin administration. Clin Exp Dermatol 1989;14:261.

6. Cortina $P$, Garrido JA, Tomas JF, Unamuno $P$, Armijo M. 'Flagellate' erythema from bleomycin. With histopathological findings suggestive of inflammatory oncotaxis. Dermatologica 1990;180:106-109.

7. Ziemer $\mathrm{M}$, Goetze $\mathrm{S}$, Juhasz $\mathrm{K}$, Elsner P. Flagellate dermatitis as a bleomycinspecific adverse effect of cytostatic therapy. Am J Clin Dermatol 2011 ;12:6876.

8. Todkill D, Taibjee S, Borg A, Gee BC. Flagellate erythema due to bleomycin. Br J Haematol 2008;142:857.

๑Copyright 2019 by Turkish Society of Hematology

Turkish Journal of Hematology, Published by Galenos Publishing House

Address for Correspondence/Yazışma Adresi: Esra TURAN ERKEK, M.D.,

1ütfi Kırdar Training and Research Hospital, Clinic of Hematology, İstanbul, Turkey

Y7y Phone : +90 5334478595

回的. E-mail : dresraturan@gmail.com ORCID-ID: orcid.org/0000-0001-7206-6699
Received/Geliş tarihi: 12 September 12, 2018 Accepted/Kabul tarihi: 2 January 02, 2019

DOI: 10.4274/tjh.galenos.2019.2018.0317 